JOURNAL OF SECURITY AND SUSTAINABILITY ISSUES ISSN 2029-7017 print/ISSN 2029-7025 online

2019 December Volume 9 Number 2 http://doi.org/10.9770/jssi.2019.9.2(22)

Scopus

\title{
INDUSTRIAL ZONE DEVELOPMENT AND INTERNAL MIGRATION ISSUE IN VIETNAM: EVIDENCE FROM BINH DUONG PROVINCE
}

\author{
Tran Thi Bich Ngoc ${ }^{1}$, Galina Anzelmovna Barysheva², Tran Duc Trung ${ }^{3}$ \\ ${ }^{1}$ Hanoi University of Science and Technology, School of Economics and Management, 1, Dai Co Viet, Hanoi, Viet Nam \\ ${ }^{2}$ Tomsk Polytechnic University, 634034, Belinsky Street, 53 a, Tomsk, Russian Federation \\ ${ }^{3}$ Hanoi Electric Power University, 235 Hoang Quoc Viet, Hà Nội, Viet Nam \\ E-mails: ${ }^{1}$ professor.tran.thibichngoc@gmail.com
}

Received 15 March 2019; accepted 18 October 2019; published 30 December 2019

\begin{abstract}
Vietnam is still classified as a low-income country with GDP per capita at 2,587 USD in the year 2018, as per the classification by World Bank Atlas method. Therefore, industrialization is set as an appropriate policy for economic development. In Vietnam, industrial zone establishment is planned, developed and controlled by the state in order to accelerate the industrialization process. This article discusses about the importance and impact of industrialization and ongoing internal migration, as a result of industrial development, on socio-economic development by reviewing the relationship among them using multivariate statistical and comparative research methods. Case study research methodology has also been used by the researchers to examine the positive and negative impacts of immigration on infrastructure of destination locality. The article presents the statistical data and the practical experience gained in Binh Duong province which has a huge number of industrial zones and with highest in-migration rate in the country; a detailed analysis of the challenges faced by local governments is presented with the appropriate recommendations for policymaking.
\end{abstract}

Keywords: industrialization, industrial zone, internal migration, urban infrastructure, environmental impact

Reference to this paper should be made as follows: Ngoc, T.T.B., Barysheva, G.A., Trung, T.D. 2019. Industrial zone development and internal migration issue in Vietnam: evidence from Binh Duong province, Journal of Security and Sustainability Issues 9(2): 649-661. http://doi.org/10.9770/jssi.2019.9.2(22)

JEL Classifications: O13, O14, O15, O18, O44, P48, R23, Q50, Q51, Q56, R11

Additional disciplines: ecology and environment; environmental engineering

\section{Introduction}

The process of industrialization is an inevitable path to be followed for the economic development of middle- and low-income countries. In developing countries, economic growth has always been emphasized as an important and essential base to solve a row of social issues such as income inequality, poverty, social insurance, general education, etc.

The development of Industrial Zone (IZ) or Industrial Park (IP) is considered as a crucial policy to promote the industrialization and modernization of the country (Bezpalov et al., 2019; Batkovskiy et al., 2018; Fomina et al., 2018; Mikhaylov, 2018).

IP refers to an area which is set aside for industrial facilities without the explicit purpose of facilitating or promoting the provision of common infrastructure and services (UNIDO, 1997; Falcke, 1999; Golovina, 2013; Tatarkin, 2013; Garina et al., 2017). 
The role played in the development of IZs confirmed that the IPs are essentially important in the process of promoting industrialization, modernization, contribution to the development of the country's infrastructure, upliftment in the competitiveness of industrial plants, acquisition of labour force and support to control potential pollution and innovation links followed by scientific research (Azizov, 2014; Sosnovskikh, 2017; Noufal, Ramachandran, 2016; Sugiantiningsih et al., 2019; Rahayu et al., 2019). But the close relationship between IZ establishment and Internal Migration (IM) within the country has not been clearly investigated. Vincenzo Bovea and Leandro Elia (2017), in their study of migration that discussed about its diversity and impact on economic growth, used data on global bilateral migration during 1960-2010 to compute diversity indices and stated that those migrants who move from one country to another carry a new range of skills and perspectives which nurture technological innovation and stimulate economic growth. At the same time, increased heterogeneity may undermine social cohesion; create coordination and communication barriers, and adversely affect the country's economic development. In other words, despite any reason, migration has both positive as well as negative impacts on economic development of the host country or destination places.

In Vietnam, regarding the relationship among IZ development, labour market demand and internal IM, $\mathrm{Cu}, \mathrm{Chi}$ Loi (2005) used comparative methods and economic growth models and found that the industrialization of Vietnam is characterized by the creation of dynamic economic zones in different parts of the country. The strong development in cities and industrial areas has generated sufficient jobs for migrants who are willing to work and take any job that helps in improving their life.

The first IZ was established in the year 1957 at Viet Tri town, Vietnam. By the end of 2018, Vietnam has a total of 326 IZs established across the country, with 249 already in operation (Shira, 2019). The household data report titled 'The 2015 Internal Migration Survey' conducted by Vietnam General Statistics Office (GSO) with United Nations Population Fund (UNFPA) cooperation concluded that 13.6 percent of Vietnam's population are migrants. In comparison with other countries in Southeast Asia, this rate is not high as observed in Cambodia (29.8 percent), Myanmar (19.3 percent), Timor-Leste (17.7 per cent) and Lao PDR (16.7 percent) (UNESCO, 2018). This study is limited to assessing the impact of IZ development and ongoing massive IM in Vietnam on socio-economic development of the localities inhibited by migrants. The current study aims at understanding the establishment of IZs, current IM issues and its possible impacts to ensure sustainable development.

\section{Materials and methods}

To highlight the reasons why Vietnamese move from one place to another, the current study used a model of migration research i.e., "Push and Pull factors" to identify the behavior of Vietnamese migrants in the context of country's industrial development. Push and Pull factors are known in the form of a model that explains why people migrate. Push factors encourage people to leave their native and settle elsewhere, while pull factors attract migrants to new place (Grigg, 1977; Rasool et al., 2012; Škuflić et al., 2018; Todorov et al., 2018).

The comparative research method was also used by the authors to analyze the impact on social-economic development of the migrant-accepting localities. The linkages between IZ development and migration and their impacts on comprehensive sustainable development of destination locality were determined by authors and were confirmed on the basis of data from published studies, official statistics from Vietnam's GSO and statistics on economic-social development of Binh Duong province as it is one of the provinces that exhibit rapid economic growth, dynamic industrial development and highest net-migration rate in Vietnam.

\section{Results}

\subsection{Vietnam internal migration: An overview of changes in the nature and motives of IM}

The population in Binh Duong province has mechanically increased, thanks to massive immigration, as a consequence of rapid industrial development and IZ expansion. A case of high net-migration rate (Table 1), population growth and IZ development in Binh Duong are typical evidence for the relationship among them. 
Table 1. Binh Duong Migration rate in 2005-2017 (\%)

\begin{tabular}{|c|c|c|c|c|c|c|c|c|c|c|c|}
\hline & 2005 & 2008 & 2009 & 2010 & 2011 & 2012 & 2013 & 2014 & 2015 & 2016 & 2017 \\
\hline In-migration rate & 27.2 & 42.3 & 73.2 & 89.6 & 64,8 & 59,1 & 54,5 & 70.2 & 52.0 & 32.3 & 30.6 \\
\hline Out-migration rate & 9.2 & 15.2 & 5.1 & 15.0 & 22,1 & 10,2 & 19,9 & 18.2 & 10.0 & 8.8 & 6.7 \\
\hline Net-migration rate & 18.0 & 27.1 & 68.1 & 74.6 & 42,7 & 48,9 & 34,5 & 52.0 & 42.0 & 23.5 & 23.9 \\
\hline
\end{tabular}

Source: GSO, 2018b, pp. 113-118

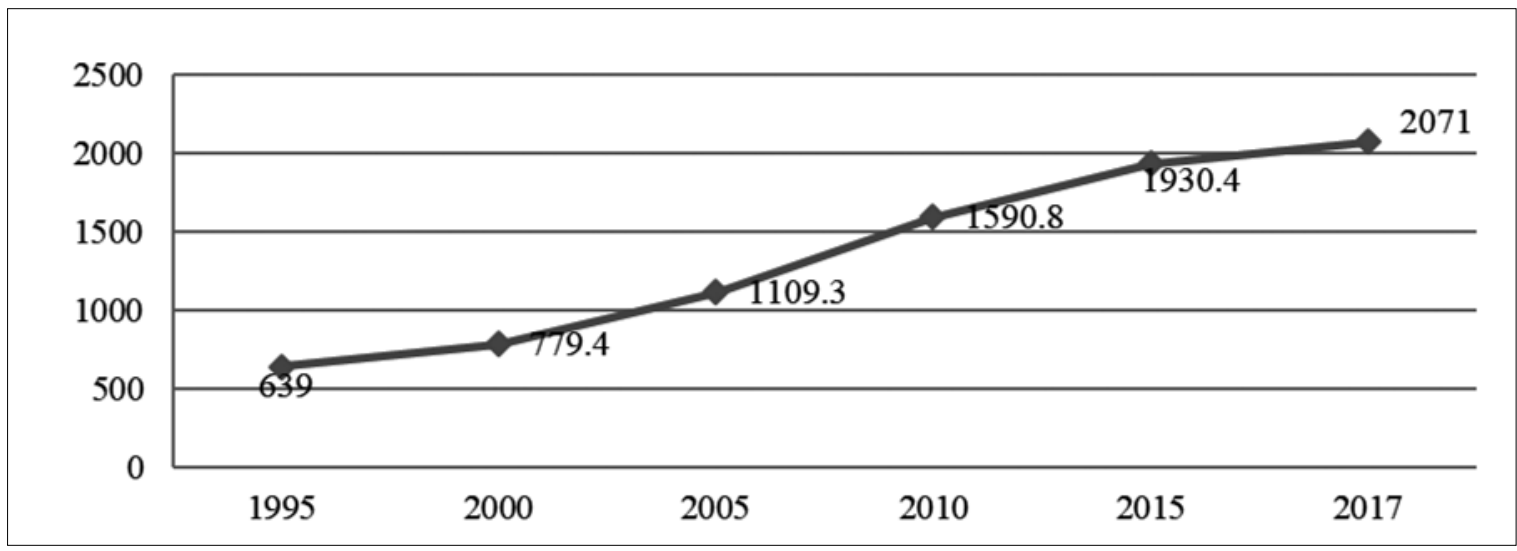

Figure 1. Binh duong population growth in $1995-2017$ (thousand people)

Source: GSO 2011, 2018a, 2018b

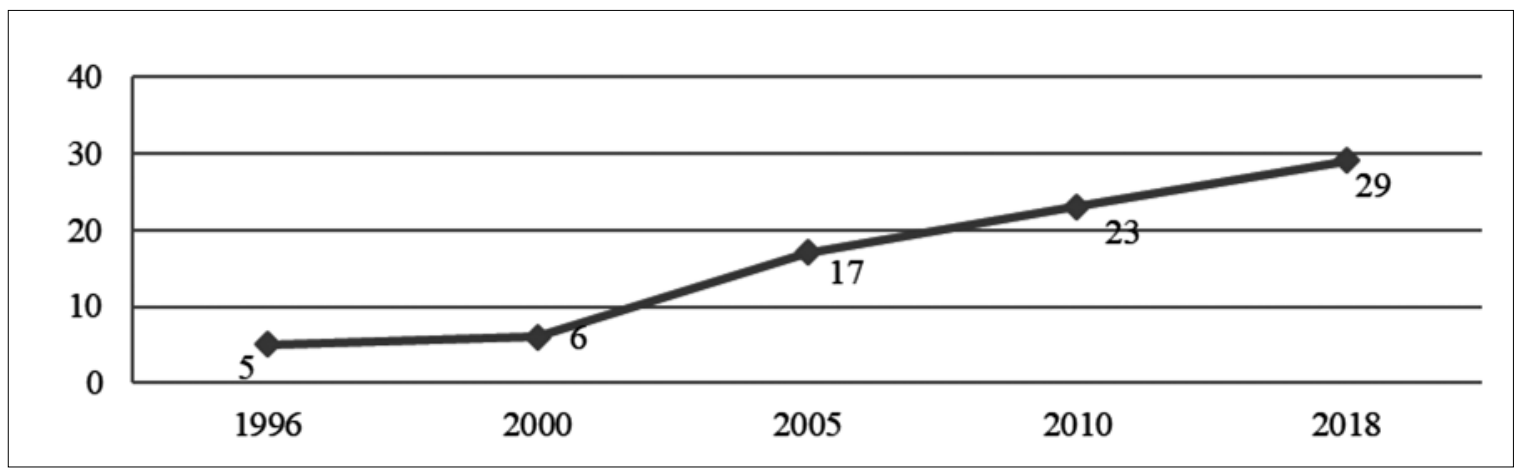

Figure 2. Binh Duong IZ development in 2006-2018

Source: Binh Dương IZ Authority, 2018

Nguyen, Thi Hien (2016), when studying the economic situation in Binh Duong province, discovered the fact that economic growth is directly proportional to population growth. The authors used the secondary statistical data presented in Figures 1 and 2 and Table 1 to evaluate this statement and define the relationship between IZ development and ongoing IM.

The results of 'The 2015 Internal Migration Survey' shown in Figure 3, contribute to the evaluation and analysis of characteristics of the migration flows that occurred due to socio-economic changes in the recent years. The migration increased in the age group of 15-19 from 11.5 percent in 2004 to 13.1 percent in 2015 denoting the education and early youth employment as reasons for growth in migration trend. Next, the largest migration rate ( 72 percent) contributed by the young people group aged in the range of 20-39 who often move from poor rural areas with the hope to improve their life. 


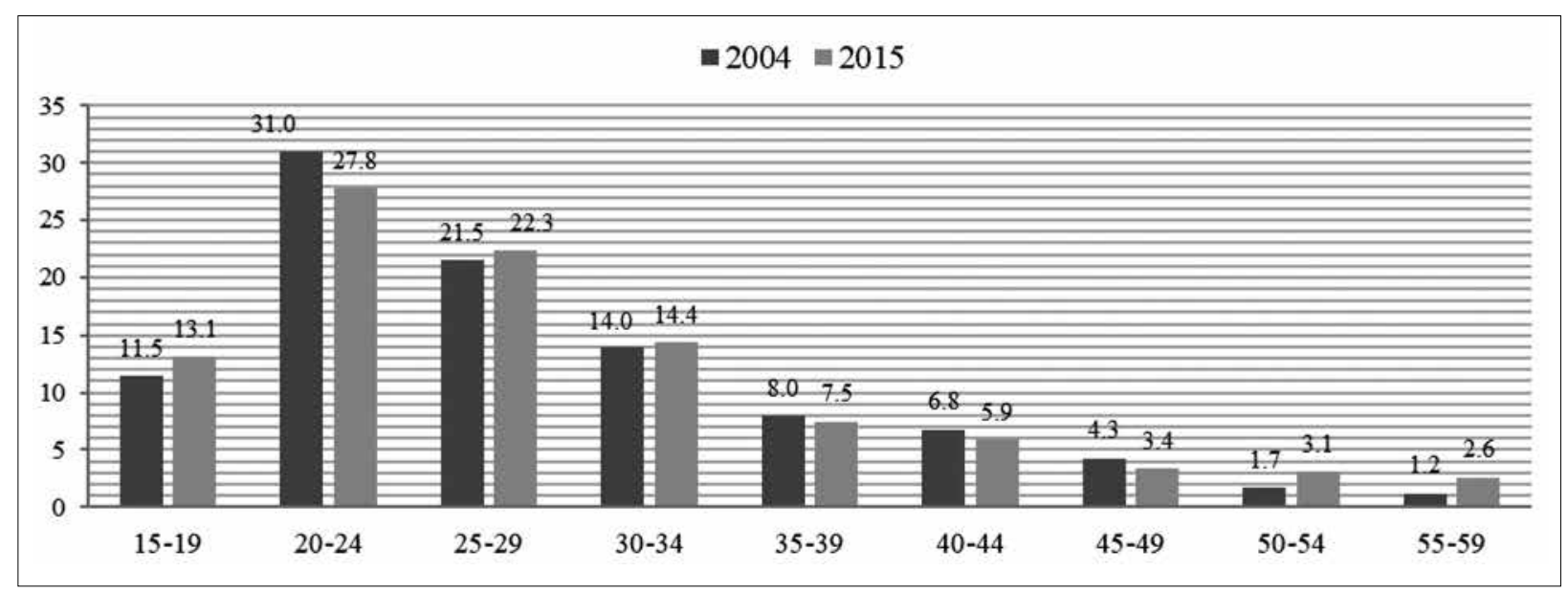

Figure 3. Age structure of migrants of the 2004 and 2015 migration surveys (\%)

Source: GSO, 2016, p. 42

\subsection{Impact of IZ development in Vietnam}

\section{Positive impacts}

In the context of Vietnam, IZs have positive impact on social-economic development mentioned below.

Contribution to economic growth and restructuring of national and regional economy; accelerating the process of industrialization and urbanization.

A country's economy growth is associated with industrialization process and IZ development. It can be noted from Figures 1 and 2 that the positive increase in country's GDP in accordance to the number of IZs simultaneously. Economic structural change is commonly understood as the change in distribution of economic activity and productive factors among various sectors of the economy. The economic sector data presented in Figures 4 and 5 shows a decrease in the rate of agriculture and increase in the rate of industry and services towards the structure of GDP. For example, in the national economic structure of 1990, agriculture, forestry and fishing sector contributed 38.74 percent, industry and construction sector accounted for 22.67 percent whereas the service sector contributed 38.59 percent (Tax-less subsides on production has not been separated). However, in 2018, the data for the relevant areas were 14.57 percent, 34.28 percent and 41.17 percent respectively (Taxless subsides on production was 9.98 percent). The same trend was observed in the provincial level too i.e., in provincial GRDP of Binh Duong province. The corresponding figures were 26.2 percent, 45.5 percent and 28.3 percent for 1996, and 3.08 percent, 63.87 percent and 23.94 percent (the Taxes less subsides on production was 9.98 percent 9.11 percent) for 2018 . 


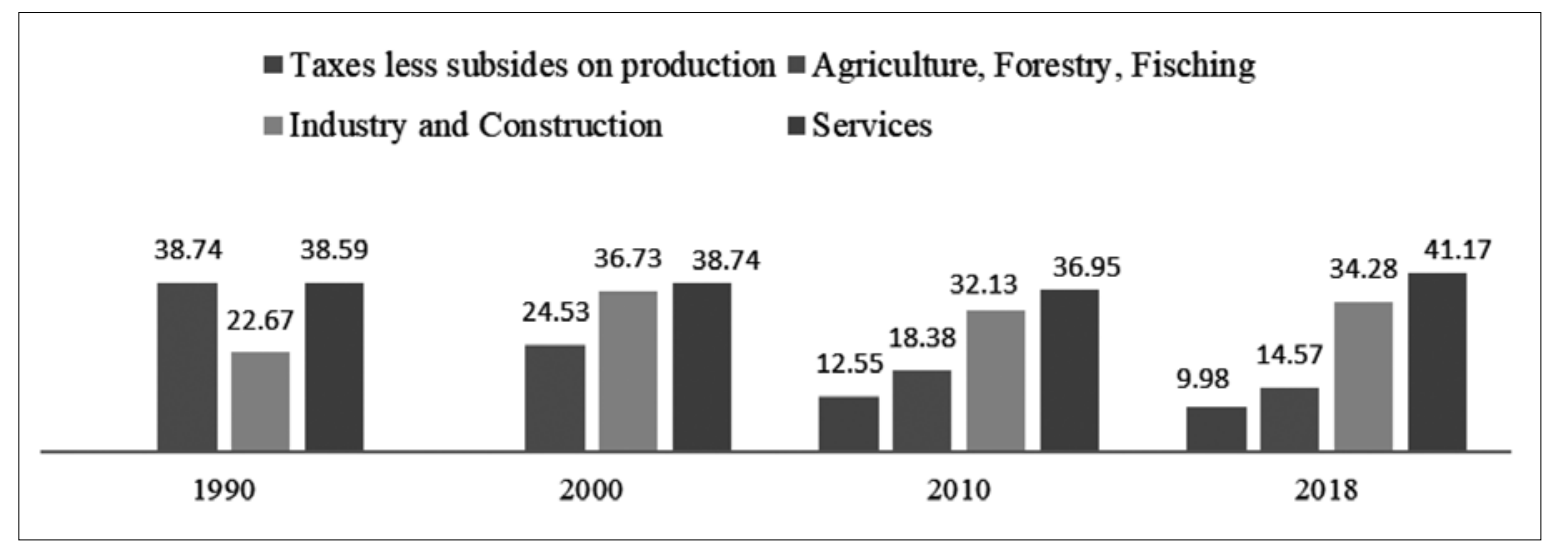

Figure 4. Vietnam's GDP structure in period of 1990-2018 (in \%)

Source: GSO, 2018b

Note: before 2010 the Taxes less subsides on production section has not been separated.

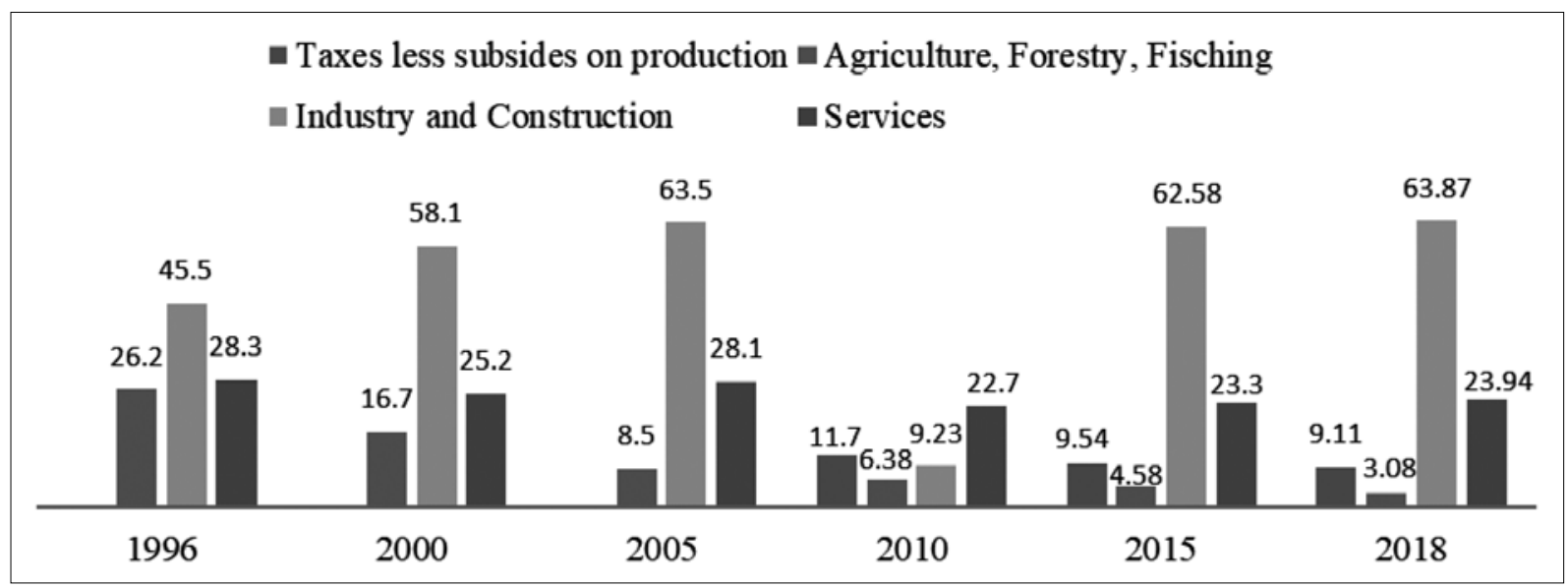

Figure 5. Binh Duong's 2018 GRDP structure in 1996-2018 (in \%)

Source: Binh Duong Statistics Office, 2018

Note: before 2010 the Taxes less subsides on production section has not been separated.

The process of urbanization has a close relationship with industrialization and IZ development planning, which is one of the factors that stimulates migration and accelerates urbanization in the past two decades (Tables 1 and 2).

Table 2. Net-migration rate by region of Vietnam in 2010-2017 (in percent)

\begin{tabular}{|c|c|c|c|c|c|}
\hline Region & 2010 & 2014 & 2015 & 2016 & 2017 \\
\hline Red River Delta & 0.5 & -0.5 & 0.0 & 0.5 & 0.0 \\
\hline Northern midlands and Mountain areas & -3.9 & -2.0 & -1.9 & -2.5 & -1.1 \\
\hline Northern Central and Central Coastal areas & -5.7 & -1.8 & -1.8 & -1.1 & -0.2 \\
\hline Central Highlands & -0.3 & 1.6 & -1.1 & -2.4 & -0.7 \\
\hline South East & 19.9 & 11.2 & 9.7 & 8.4 & 5.6 \\
\hline Mekong River Delta & -8.4 & -6.7 & -5.4 & -4.6 & -4.0 \\
\hline
\end{tabular}


The rural areas that surround the city, where IZs located, were merged into the city; developing rural areas, where IZs were arranged, were altered in accordance to the Master plan development into satellite towns of industrial centers or big cities. The suggestions in this study were confirmed by the results of 'The Vietnam Population and Housing Census 2009' which identified several exceptions related to provinces, where high concentration of IZs exists with huge demand for migrant labour (GSO, 2011). The presence of those exceptions and outliers refers a diversification of pull factors.

\section{Creation of favorable environment to attract foreign investment and mobilize internal capital}

According to World Bank Atlas method classification, Vietnam was classified as a low-income country with GDP per capita at 2,587 USD in the year 2018 (GSO, 2018a) whereas the country's economic growth model is based on export-led growth and domestic demand. Therefore, the investment capital for the expansion of production has a great demand, and attracting the investment capital is one of the Vietnam government's top policies on socio-economic development (Progunova and Bogatyreva, 2019). By the end of 2018, IZs and other economic zones attracted 7,500 domestic projects worth 41.75 billion USD and around 8,000 foreign projects with a total capital over 145 billion USD (Shira, 2019).

\section{Creation of jobs and promoting the formation of the labour market}

In 1986, the central-planning economic model was preferred in Vietnam; the allocation of all resources, including the labour force, must comply with the order and plans of the State. However, as per the policy of renovation ("ĐổiMới" in Vietnamese) and "Open Door", the government implemented vigorous reforms on the economy transition from centralized planning economy to market one (Nguyen, 2014). The companies especially, light industry enterprises located in IZs and specialized in manufacturing textiles, garments, footwear, and electronics, etc., attract huge number of employees. In the entire country, the headcount of workers occupied in industry and construction sector increased from 5 million (13 percent of the total) in the year 2000 (GSO, 2006) to 13.8 million (25.7 percent of the total) in 2017 (GSO, 2018b).

Contribution to create a new \& modern infrastructure system in the country for long-term development and solving environmental protection issue

The IZ development is planned and controlled by the government of Vietnam as a step in long-term socio-economic development strategy. A set of quality parameters such as economic efficiency, social and environmental protection was determined and applied for IZ planning and designing since it is a prerequisite under Vietnam laws. Moreover, a complete IP needs to have its own infrastructure such as basic, technical, social and environmental systems so that it can operate effectively and sustainably while at the same time, it also reduces the environmental litigation risks and improve its persona.

\section{Factors that induce large-scale IM inside the country}

It is to be noted that the highest net-migration rate observed in Binh Duong province (68.1 percent in 2009; 74.6 percent in 2010 and 42.0 percent in 2015) and whole country are presented in Tables 1 and 3 for the year 2010-2017 when most of IZs were under construction. The differential variation of net-migration rate by region (Table 2) and percentage distribution of migration flows show the size of the population movement throughout the country. The '2015 National Internal Migration Survey' addressed a series of problems that occur due to migration. The contribution from rural-urban migration flows was high, accounting for about 50 percent of overall migrants (Table 3). 
Table 3. Percentage distribution of migration flows from places of birth to the current residence by types of migration

\begin{tabular}{|c|c|c|c|c|}
\hline Migration flows & Total & Intra-provincial migration & Inter-provincial migration & Not identified \\
\hline Total (\%) & 100 & 100 & 100 & 100 \\
\hline Urban - Urban & 18.0 & 4.9 & 7.7 & 5.4 \\
\hline Rural - Urban & 49.8 & 13.6 & 33.4 & 2.8 \\
\hline Urban - Rural & 2.9 & 0.9 & 1.9 & 0.1 \\
\hline Rural - Rural & 29.2 & 4.7 & 17.1 & 7.4 \\
\hline Number of migrants* & 4969 & 1231 & 2838 & 900 \\
\hline
\end{tabular}

Source: GSO, 2016;

*number of migrants responded to survey

Negative impacts

Pressure on the urban infrastructure system and public infrastructure due to fast growing number of IZs and abrupt population growth

Over 81.5 percent of migrants inhabited in rented houses in the provinces or big cities where IZs employ a large number of migrant workers in which most (61.7 percent) are self-migrants. The remainders migrated with family members such as spouse, children, parents, relatives and friends (GSO, 2016). Moreover, the '2015 Internal Migration Survey' has shown that only one-third (31.7 percent) of the migrants possess professional and technical qualification and over a quarter (27 percent) graduated from high school (GSO, 2016). Binh Duong province has an area of $2694.6 \mathrm{~km}^{2}$; population density (person $/ \mathrm{km}^{2}$ ) got increased from 252 in 1997 to 601 in 2010 (Nguyen, 2012) and finally 769 in 2017 which is nearly triple the number of country's average population density (283 person $\left./ \mathrm{km}^{2}\right)(\mathrm{GSO}, 2018 \mathrm{~b}, \mathrm{pp}$. 79-80). The population of the province has tripled within two decades i.e., 1997-2017 (Figure 1).

The analysis and comparison of these real figures help to conclude that (a) a sudden population growth relates to an increase in the number of IZs during the same period; (b) in-migration is the main reason of population growth dominated by 'push and pull factors' according to the basic supply and demand law in the labour market. The indispensable role played by the migrants in the local development of Binh Duong province can be experienced through their absolute majority among workers who work in IZs: the total number of workers as of 1998 was 18,737 persons, of which 16,362 were immigrants i.e., 87.32 percent; by the end of 2016, these numbers increased to 373,433 and 335,429 (90 percent) respectively (Pham, 2018).

\section{Environmental impact}

According to the data registered by the Department of Environmental Protection, Binh Duong in July 2015, the total industrial wastewater flow in the province accounted for $140,000 \mathrm{~m}^{3}$ per day, of which $69,214 \mathrm{~m}^{3}$ from IZs and industrial cluster; the total volume of industrial solid waste reached 5,128 tons per day, (4,808 tons of non-hazardous industrial solid waste and 320 tons of hazardous solid waste). IZs located in the province cause huge toxic emissions, including dust 32,078 tons, $\mathrm{SO}_{2}: 349$ tons, $\mathrm{CO}: 8,910$ tons and NOX: 60 tons on an average every year (Pham, 2018).

\section{Increase in the social problems including crime}

According to the statistics of Binh Duong Police Department, from 2012 to 2016, there were 4,782 criminal offenses happened in IZs and industrial clusters, accounting for $82.5 \%$ of the total number criminal cases of the whole province (Phuong, 2017). This is another example that confirms the influence of IZ development on community life. In Dong Nai province from 2007 to 2017, a total of 24,728 crime cases with 41,890 defendants were tried by Dong Nai province's People's Courts, of which 1,947 crimes with 2,821 defendant perpetrated crimes were punished in IZs (Le, 2018). 


\section{Discussion}

Through the investigation of relationship between the development of IPs and ongoing IM in Vietnam and in accordance to the analysis of successes of Binh Duong province in planning and implementing the development policies, turning negative impacts of the IZ establishment and migration issues into opportunities, this research paper proposes some recommendations, to which policy makers, advised to pay attention.

\subsection{Addressing negative impact of IZ development and IM issue on infrastructure of migrant-receiving localities: Evidence from Binh Duong province}

Huge immigration due to IZ development mounts heavy pressure on provincial infrastructure system that in turn threatens the local sustainable development. However, Binh Duong's provincial government has made reasonable development policies to reduce the pressure and ensure normal life in the province. Binh Duong Province's Master Plan (MP) named 'Master Plan on Socio-Economic Development of Binh Duong province through 2020 and supplemented master plan through 2025' on socio-economic development was approved by the Prime Minister in the year 2007 (Decision No. 81/2007/QD-TTg) and it was modified in 2014 (Decision No. 893/QD-TTg). Based on this MP, the plans and programs for the development of all sectors and fields were also formulated, including that of urban infrastructure development planning.

\section{Housing}

In order to promptly provide the accessible housing for low-income workers, Binh Duong province government had approved the program, 'Program No. 27-CT/TU' dated September 20, 2011 on social housing development during 2011 - 2015 with a goal to build $1,250,000 \mathrm{~m}^{2}$ of total internal floor area so as to meet the demand for housing 125,000 workers who are employed in IZs. To implement this policy, the province has taken measures such as (1) providing necessary land fund for construction companies so that cheap apartments with floor area of $30 \mathrm{~m}^{2}-50 \mathrm{~m}^{2}$ can be built and sold or rented to low-income workers; and (2) socializing housing provision by mobilizing the resources of local residents, private investors and companies located in IZs; The program yielded surprising and unexpected results. In this period, 82 social housing projects were incorporated with nearly $3,700,000 \mathrm{~m}^{2}$ of internal floor area that tripled the target set for the period thus meeting the housing demands of more than 600,000 people. Among this data, more than $3,000,000 \mathrm{~m}^{2}$ of boarding houses (equivalent to 182,289 apartments) were built by local individuals as well as households; $269.982 \mathrm{~m}^{2}$ were built by 200 enterprises located in IZs (Binh Duong Provincial Party Committee, 2015). The success is primarily attributed to the provincial government's policy of mobilizing possible sources of investment to social housing.

\section{Education and health care}

In 1997, Binh Duong education and training sector had 2,819 classrooms, 4,905 teachers and 160,000 students (Phuong, 2016). With blooming development in the economy, these numbers increased rapidly based on large investment in education. According to '2018 Binh Duong Statistics Office Report', up to November 2018, in the whole province, there are 723 educational and training institutions which consists of 365 kindergartens and preschools, 272 primary and high schools, 07 universities, 01 college with 78 professional secondary schools and vocational training centers. The share of private education sector is also relatively high i.e., 30 percent of the total number of education and training institutions; especially in preschool education, this share is about 66 percent (Binh Duong, 2018). The planning for human resource development in Binh Duong province for the period 2011-2020 refers to investment in education and training fields from domestic and foreign organizations, individuals and business owners. 
Table 4. Number of health establishments and number of doctors in Binh Duong in 2005 and 2017

\begin{tabular}{|c|c|c|c|c|c|c|c|}
\hline & \multirow{2}{*}{$\begin{array}{c}\text { Total } \\
\text { number of } \\
\text { patient beds }\end{array}$} & $\begin{array}{c}\text { Total } \\
\text { number of } \\
\text { doctors }\end{array}$ & $\begin{array}{c}\text { Total number } \\
\text { of health } \\
\text { establishments }\end{array}$ & Hospital & $\begin{array}{c}\text { Sanatorium and } \\
\text { rehabilitation } \\
\text { hospital }\end{array}$ & $\begin{array}{c}\text { Regional } \\
\text { polyclinic }\end{array}$ & $\begin{array}{c}\text { Medical service unit in } \\
\text { communes, precincts, } \\
\text { offices and enterprises }\end{array}$ \\
\hline 2005 & 1825 & 403 & 105 & 9 & 1 & 5 & 89 \\
\hline 2017 & 3027 & 729 & 123 & 11 & 1 & 18 & 91 \\
\hline
\end{tabular}

Source: Binh Duong People's Committee, 2018

The grown in healthcare sector is exponential i.e., in the 12 years from 2005 to 2017, the number of doctors and hospital beds has nearly doubled; the number of medical facilities increased by 20 percent (Table 4). This achievement is also a part of the implementation of the Plan for the development of care, protection and improvement of people's health in Binh Duong province to 2015 and orientations towards 2020 approved by the Provincial People's Committee Decision No. 44/2012/QD-UBND October 16, 2012. According to the decision, the total capital for the period of 2012-2015 was 5,352 billion VND, of which 2,992 billion VND was allotted from budget and 2,360 billion VND from socialized (private organization and individual) sources. The '2018 Provincial People's Committee Report' on socio-economic situation inferred that in 2018, the number of beds to 10,000 people were 23 and the number of doctors to 10,000 people reached 7.46 which is still lower than the goals set in the provincial plan and the targets of the national strategy to protect, care, and improve public health during 2011 - 2020 period, orientation towards 2030 (26 and 9 by 2020).

\section{Transport}

The provincial government always combines the urban development and the development of public transport with an aim to build civilized and modern urban areas. The traffic and transport system of Binh Duong province was planned and invested in the direction of intimately-connecting the satellite towns and industrial centers with new city center of Binh Duong. It was specified in 'The Binh Duong's Transport Master Plan to 2020 with orientation towards 2030' that: (1) planning transportation absolutely complies with long-term MP on provincial socio-economic development, ensuring convenient and safe traffic; (2) taking the planning of transport infrastructure development so that it would be able to connect the provincial transport system with the infrastructure of IZs, the national transport system and the southern key economic provinces. As per the statistics published in 1997, Binh Duong province had only 2,186 km roads of low quality under poor conditions. The provincial government has focused on mobilizing all the resources to develop transport networks. As of December 2016, the total length of the road system constructed in the province was $7,421 \mathrm{~km}$ (Saisho, 2017).

\section{Electricity supply}

In Binh Duong province, the demand for electricity from the foreign companies in and around industrial clusters, IZs and public service buildings such as hospitals, provincial government buildings, government offices and schools etc. is high. Therefore, along with infrastructure, the improvement measures with regards to the electricity supply such as new establishment, expansion or renewal of lines, substations, and installation of in-house electricity production facilities using renewable energy (sunlight, wind) are being implemented to reduce power consumption from the national grid and to stimulate energy saving as well as green energy use (Saisho, 2017).

\section{Water and waste treatment}

According to the data reported by the Department of Environmental Protection, Binh Duong in July 2015, 90\% of the total industrial wastewater, industrial solid waste including hazardous solid waste in the province were collected, processed or destroyed (Pham, 2018). Besides the urban solid waste treatment plants and waste- 
water treatment stations, 100 percent of the factories located in IZs have in-built waste treatment unit, water supply and drainage system whereas these wastewater treatment systems are connected with IZ general waste discharge system. By 2016, 100\% of IZs were completely equipped with wastewater treatment system with a total design capacity of $107,600 \mathrm{~m}^{3}$ per day (Nguyen, 2016). It should be noted that there is a wide participation from the private sector in addressing key issues that are caused by migration as it mounts the pressure on urban infrastructure and public services of Binh Duong province.

Though IM becomes a common phenomenon, the characteristics of the migrants were relatively diverse: 13.6 percent of the total country's population are migrants; the number of female migrants were 52.4 percent of the total population; only one-third of the migrants possess professional and technical qualifications; 31.4 percent of migrants move with their families (GSO, 2016). So, vocational training or retraining deserves more attention in development plans and policies. Migration-related policies should be responsive to most of the essential needs of the immigrants in terms of housing, healthcare, education, continuation of the disrupted education among migrant children in school ages, technical training for migrant workers and gender aspect.

Public-Private Partnership model, commonly termed as 'Socialization' was successfully applied in Binh Duong province, Vietnam, in urban infrastructure construction and meeting the needs of the migrants for affordable housing, accessible healthcare service, pre-school and general education with vocational training. Overcrowding puts a tremendous pressure on the infrastructure system of the city resulting in the economic losses and great inconvenience to people (travel time, transportation cost, traffic accidents, health problems, medical and other costs, etc.) thus in turn hinder the sustainable development. Thus, at national level, there must be coordination between central and local state agencies to reserve aside the areas or land fund for urban infrastructure development, public service and facilities and resettlement of residents. There must also be a coordination to formulate the criteria set for designing and building the infrastructure of IZs and firms located in it while setting up an IZ. This measure is very important as high population density and private constructions of the residents obstruct the infrastructure development in public service network incurring huge cost for site clearance. A good example for ground clearance would be Hanoi city. In order to construct the road spanning 2,274 m, about 785 billion VND (equivalent 35 million USD) was spent whereas the remaining amount over 6,000 billion VND was incurred only on land clearance and resettlement support (Trong Phu, 2018).

Currently, numerous issues with regards to technical training and the quality of graduates passed out from higher educational institutions need to be solved at the national level. When the data from '2018 Vietnam Labour Market Updated Newsletter of the Ministry of Labour, Invalids and Social Affairs (MOLISA)' was analyzed, it was found that the number of people in the working age population of 15 to 60 years old (not taking disabled and people abroad into account) accounted for 55.64 million of which only 12.36 million (22.22 percent of the total) were appropriately trained at different levels and possess vocational certificates. The ratio of the structure of higher education to secondary (or college) and junior vocational education, calculated by authors, based on the updated bulletin of 2018 respectively was 1/0.93/0.35 (MOLISA, 2018). This is a warning towards the imbalanced structure of labour force training and contradicts the needs for a large number of qualified specialists and junior workers in industries. Moreover, the quality of education and training was also assessed in the 'Skills toward Employment and Productivity (STEP) Employer Survey' conducted by World Bank in the year 2011-12 at Vietnam. It was concluded that two-thirds of all international companies claim that neither the general education system nor the vocational education system was able to nurture the students with necessary skills needed at their subsequent workplace (Bodewig, 2014).

\section{Conclusions}

As discussed in the previous sections, it is the need of the hour to restructure the education and training system and improve the quality of training so as to meet the needs of economy. This can be achieved through the implementation of following measures: (1) Education and training sector have to change the vocational training structure; (2) Leveraging an effective form of 'on-demand training' that helps education and training organizations understand the needs of employers and (3) Entering into Memorandum of Understandings (MoU) 
and collaborations by the entities such as public and private educational institutions, research institutes and manufacturing enterprises for the purpose of training since these kinds of MoUs are highly useful in ensuring a quality workforce that meets the industrial demand. Industrialization is an important part of Vietnam's socioeconomic development policy. For that reason, industrialization, modernization and the IZ development are considered as optimal solutions to achieve the development. IM has occurred under the impact of pull and push factors that contributed to the creation of diverse labour market so as to meet the large labour demand of the industries. In order to address issues related to industrial development and IM in developing countries, further in-depth research is required.

\section{References}

Azizov, M. (2014). The Importance of Industrial Parks in Economic Development. Baku: Qloballaşma Prosesində Qafqaz və Mərkəzi Asya, İqtisadiyyat və Beynəlxalq münasibətlər IV Beynəlxalq Konqres Materialları https://doi.org/10.13140/RG.2.1.1476.9046

Batkovskiy, A.M., Efimova, N.S., Kalachanov, V.D., Semenova, E.G., Fomina, A.V., Balashov, V.M. (2018). Evaluation of the efficiency of industrial management in high-technology industries. Entrepreneurship and Sustainability Issues, 6(2), 577-590. https://doi. org/10.9770/jesi.2018.6.2(8)

Bezpalov, V.V., Fedyunin, D.V., Solopova, N.A., Avtonomova, S.A., Lochan, S.A. (2019). A model for managing the innovation-driven development of a regional industrial complex. Entrepreneurship and Sustainability Issues, 6(4), 1884-1896. https://doi.org/10.9770/ jesi.2019.6.4(24)

Binh Duong People's Committee. (2018). Report on the socio-economic situation 2018. Retrieved from https://www.binhduong.gov.vn/ chinhquyen/Pages/bao-cao-kinh-te-xa-hoi-chi-tiet.aspx?ItemID=103

Binh Duong Provincial Party Committee. (2015). Summary report on the implementation of the social housing development program in Binh Duong province in the period of 2011-2015, No. 369-BC/TU. Binh Duong: BDPPC.

Binh Duong Statistics Office. (2018). Report on Socio-Economic Situation in 2018. Retrieved from https://thongke.binhduong.gov.vn/ Lists/BaoCaoThongKe/TongQuat.aspx

Bodewig, C., Badiani-Magnusson, R., Macdonald, K., Newhouse, D., \& Rutkowski, J. (2014). Skilling Up Vietnam - Preparing the Workforce for a Modern Market Economy. Washington: The World Bank. D https://doi.org/10.1596/978-1-4648-0231-7

Bovea, V., \& Elia, L. (2017). Migration, Diversity, and Economic Growth. World Development, 89, 227-239. https://doi.org/10.1016/j. worlddev.2016.08.012

Falcke, C. (1999). Industrial Park: Principles and Practice. Journal of economic Cooperation of Islamic countries, 20(1), 1-10.

Fomina, A.V., Berduygina, O.N., Shatsky, A.A. (2018). Industrial cooperation and its influence on sustainable economic growth. Entrepreneurship and Sustainability Issues, 5(3), 467-479. https://doi.org/10.9770/jesi.2018.5.3(4)

Garina, E.P., Kuznetsova, S.N., Romanovskaya, E., V., Garin, A.P., PKozlova, E., Suchodoev, D.V. 2017. Forming of conditions for development of innovative activity of enterprises in high-tech industries of economy: a case of industrial parks. International Journal of Entrepreneurship, 21(3), 1939-4675-21-3-116

Golovina, T. (2013). Concept application «management future» for forecasting of financial results industrial enterprises. Journal of Contemporary Economics Issues, 1. https://doi.org/10.24194/11304

Grigg, D. (1977). E. G. Ravenstein and the 'Laws of Migration. Journal of Historical Geography, 3(1), 41-54. https://doi. org/10.1016/0305-7488(77)90143-8

GSO. (2006). Statistical Yearbook of Vietnam. Hanoi: Statistical Publishing House.

GSO. (2011). The Vietnam Population and Housing Census 2009: Migration and Urbanization in Vietnam: Patterns, Trends and Differentials. Hanoi: Vietnam General Statistics Office.

GSO. (2016). The 2015 Internal Migration Survey: Major Findings. Hanoi: Vietnam news agency publishing house.

GSO. (2018a). Social and economic situation in 2018, Monthly statistical information. Retrieved from https://www.gso.gov.vn/default_en.aspx?tabid=622\&ItemID=19043

GSO. (2018b). Statistical Yearbook of Vietnam. Hanoi: Statistical Publishing House. 
Le, N. (2018). Criminal prevention in Dong Nai province’s Industrial zones. Hanoi: Doctoral Thesis.

Loi, C. (2005). Rural to urban migration in Vietnam. In Impact of Socio-Economic Changes on the Livelihoods of People Living in Poverty in Vietnam (pp. 115-143). Institute of Developing Economies, Japan External Trade Organization (IDE-JETRO).

Mikhaylov, A.S. (2018). Socio-spatial dynamics, networks and modelling of regional milieu. Entrepreneurship and Sustainability Issues, 5(4), 1020-1030. http://doi.org/10.9770/jesi.2018.5.4(22)

Ministry of Labor, Invalids and Social Affairs. (2018). Vietnam labor market update newsletter. No. 20, Q4. Hanoi: MOLISA.

Nguyen, A. (2014). Vietnam Labor Market In The Context of International Integration. Wie's I Rolnictwo, 4(165), 83-96. DOI: 10.22004/ ag.econ.230465.

Nguyen, H. (2016). Binh Duong: Focus on developing clean Industrial Zone. Retrieved from http://khucongnghiep.com.vn/dinhhuong/ tabid/65/articleType/ArticleView/articleId/1632/BNH-DNG-Ch-trng-pht-trin-KCN-sch.aspx

Nguyen, T. (2012). Influence of industrialization on Binh Duong's population change in the period 1997 - 2010. Science journal of Ho Chi Minh City Pedagogical University, 41, 71-78.

Noufal, P., \& Ramachandran, K. (2016). Industrial parks and regional economic development: Select literature review. International Journal of Advanced Education and Research, 2(4), 98-101.

Pham, N. (2018). Doctoral thesis on the impact of industrial zones on socio-economic development of Binh Duong Province. Retrieved from https://iluanvan.com/tac-dong-cua-cac-khu-cong-nghiep-doi-voi-su-phat-trien-kinh-te-xa-hoi-tinh-binh-duong

Phuong, C. (2016). Binh Duong: 20 years of development: Vol. 12: Improving the quality of Education and Training. Retrieved from https://www.binhduong.gov.vn/thong-tin-tuyen-truyen/2016/12/410-binh-duong-20-nam-phat-trien-ky-12-nang-cao-chat-luongdelivery

Phuong, C. (2017). Crime prevention in industrial zones and clusters in Binh Duong province: Current situation and solutions. Retrieved from https://www.binhduong.gov.vn/tin-tuc/2017/03/873-phong-chong-toi-pham-tai-cac-khu-cum-cong-nghiep-tren-dia-bantinh-binh-duong-thuc-trang-va-giai-pha

Progunova, L.V., \& Bogatyreva, S.V. (2019). BRICS Intra-group FDI: Searching for Real Volumes and Ultimate Investors. 33rd IBIMA Conference: 10-11 April 2019, Granada, Spain. Retrieved June 19, 2019 from https://ibima.org/accepted-paper/brics-intra-group-fdisearching-for-real-volumes-and-ultimate-investors/

Rahayu, H.C., Sarungu, J.J., Hakim, L., Soesilo, A.M., Samudro, B.R., Lestari, E.P. (2019). Geography and Infrastructure Dimension on Poverty in Riau Province: Data Panel Approach at the Village Level. Journal of Southwest Jiaotong University, 54(5). https://doi. org/10.35741/issn.0258-2724.54.5.22

Rasool, F., Botha, C., \& Bisschoff, C. (2012). Push and Pull Factors in Relation to Skills Shortages in South Africa. Journal of Social Sciences, 30(1), 11-20. https://doi.org/10.1080/09718923.2012.11892978

Saisho, T. (2017). Promotion of Smart Community Strategy in Vietnam's Binh Duong Province. Retrieved from https://www.intechopen. com/books/urban-agglomeration/promotion-of-smart-community-strategy-in-vietnam-s-binh-duong-province

Shira, D. (2019). Vietnam's Industrial Zones - How to Pick a Location for Your Business. Vietnam Briefing. Retrieved from https://www. vietnam-briefing.com/news/vietnam-industrial-zones-how-to-pick-location-for-your-business.htm

Škuflić, L., Krpan, M., Žmuk, B. (2018). Migration and the economic crisis in the European Union member states: cluster analysis. Entrepreneurship and Sustainability Issues, 6(2), 979-1000. https://doi.org/10.9770/jesi.2018.6.2(34)

Sosnovskikh, S. (2017). Industrial clusters in Russia: The development of special economic zones and industrial parks. Russian Journal of Economics, 3(2), 174-199. https://doi.org/10.1016/j.ruje.2017.06.004

Sugiantiningsih, A.A.P., Weni, I.M., Hariyanto, T., Tutuko, P., Sedyowati, L. (2019). Enhancing Environmental Quality through Community Participation based on Traditional Rules: Empowering the New Role of Pecalang in Bali. Journal of Southwest Jiaotong University, 54(5). https://doi.org/10.35741/issn.0258-2724.54.5.16

Tatarkin, A. (2013). Innovation direction of the avarage region development in the modernization of the Russian Federation. Journal of Contemporary Economics Issues, 3. https://doi.org/10.24194/31311

Todorov, G.N., Kalinina, A.V., Rybakova, A.I. (2018). Impact of labour migration on entrepreneurship ecosystem: case of Eurasian Economic Union. Entrepreneurship and Sustainability Issues, 5(4), 992-1007. http://doi.org/10.9770/jesi.2018.5.4(20) 
Trong, P. (2018). Behind the road 'unbelievably expensive' in Hanoi. Retrieved from https://plo.vn/do-thi/giao-thong/dang-sau-conduong-dat-khong-tuong-o-ha-noi-750467.htm

UNESCO. (2018). Internal migration in Southeast Asia: an initiative to better understand migrants'experiences and develop inclusive policy responses. Retrieved from https://unesdoc.unesco.org/ark:/48223/pf0000261362

UNIDO. (1997). Industrial Estates: Principles and Practice. Vienna: UNIDO.

Tran Thi Bich NGOC is a PhD in Economics, Associate Professor, Deputy Head of the Department of Industrial Management, Hanoi University of Science and Technology. Research interests: production management; industrial policy of the region; innovation; domestic violence; sustainability development, elderly care.

ORCID ID: orcid.org/0000-0003-2184-3907

Galina BARYSHEVA is a Professor of the School of Engineering Entrepreneurship and Head of International Scientific Educational Laboratory of the Improvement of Well-Being Technologies of Older Adults, Tomsk Polytechnic University, Russia. Research interests: social entrepreneurship and regional development; innovation; sustainability, realization of the resource potential of the seniors.

ORCID ID: orcid.org/0000-0002-2746-1355

Tran Duc TRUNG is a Lecturer (Phd) at the Faculty of Economics \& Management of the Electric Power University, Hanoi, Vietnam. Research interests: emerging market issues, social changes and sustainable development, behavioural finance.

ORCID ID: orcid.org/0000-0002-5168-8058 